geology. These were The Embryonal Volcanoes of Suabia (Schwabens 125 Vulkanembryonen), 1892-8, and his theories on the origin of the Ries of Noerdlingen and the neighbouring cryptovolcanic basin of Steinheim (1901-1913). The latter were frequently atacked (Koken, Penck, Kranz, etc.) and even to-day after thirty years this greatest riddle of German geology is still the centre of exciting discussions. Nevertheless if the theories have changed the fundamental work was done by Branca.

In palaeontology his main work was on the development of the Ammonites, on fossil fish and the origin of man. He organized the great Tendaguru Expedition to former German East Africa, the results of which are now to be seen at the Natural History Museum of Berlin and remain an indissoluble monument to this great. geologist.

Herbert P. T. Rohleder.

\title{
CORRESPONDENCE.
}

TO ALL THOSE INTERESTED IN ECONOMIC GEOLOGY.

SIR,-This is an earnest appeal for help towards establishing an Annotated Bibliography of the International Literature of Economic Geology.

No country is sufficient unto itself and least of all in science. All geologists probably realize this ; and those who employ geologists should likewise realize that the efficiency of their staff is largely dependent upon familiarity with the progress of science throughout the world. We can not afford isolation or imperfect knowledge. A plan worked out by the Division of Geology and Geography of the National Research Council at Washington for such an Annotated International Bibliography has been approved by the Council itself, the U.S. Geological Survey, the U.S. Bureau of Mines, the American Institute of Mining and Metallurgical Engineers, and the Society of Economic Geologists.

The plan includes a subscription fund of at least $\$ 18,000$, which will provide means for the editorial work for from five to seven years. The National Research Council has agreed to serve as treasurer and custodian of these funds, to be expended in accordance with the usual customs of the Council. Tentative arrangements have been made with an experienced bibliographer to take charge of the work. The Economic Geology Publishing Company has agreed to publish the bibliography, which is to be issued in two volumes per year, aggregating about 400 pages, and to sell it for an equitable price, which will probably be about $\$ 2.50$ per volume, which should pay for paper, printing, and distribution.

It will be observed that the present plan is restricted to economic geology and calls for funds to carry on the work for a limited time only, but it is felt that it will prove so useful, indeed, so indispensable, 
that little difficulty will be experienced in providing for its indefinite continuation. The subjects to be covered include articles on all metallic and non-metallic deposits (including petroleum and gas), hydrology, engineering geology and soils (in so far as related to geology). Publications in other branches of geology will be included if they have any bearing on economic geology.

Subscriptions will not be called for until the amount deemed necessary has been subscribed. Pledges should be sent to Professor W. Lindgren, National Research Council, Washington, D.C., U.S.A.

W. LINDGREN.

E. De Golyer.

G. F. Loughurn.

W. C. Mendenhall.

R. A. F. Penrose, jun.

\section{ANNOUNGEMENTS AND INQUIRIES.}

In unofficial connection with the meetings of Section $\mathrm{C}$ (Geology) of the British Association for the Advancement of Science at Glasgow, 5th to 12th September, it is proposed to run two long excursions. One, preceding the meeting, is to be held from 30th August to 4th September (approximately), and is to be conducted by the President, Mr. E. B. Bailey, B.A. From Ballachulish, as centre, the recumbent folds and slides of Ballachulish, the cauldron subsidences of Glen Coe and Ben Nevis, and the parallel roads of Glen Roy, will be inspected.

An excursion to Arran from 12th to 19th September (approximately) after the meeting will be conducted by Dr. G. W. Tyrrell. Amongst the phenomena to be seen in this classic island are the tectonics of the Northern Granite, Hutton's unconformity, the U-valleys of Glen Rosa and Glen Sannox, the Arenig (?) pillow lavas and cherts of North Glen Sannox, the Central Ring Complex and hybrid rocks, composite sills and dykes of Tormore, Bennan, etc., the Arran Dyke Swarm, etc.

Owing to the difficulty of securing accommodation the parties must be limited to from 20 to 25 persons. It is hoped that foreign guests will attend. In order that arrangements may be made in good time, those desirous of attending these excursions are requested to notify Dr. G. W. Tyrrell, University of Glasgow, as soon as possible. 